ENTREPRENEURSHIP AND SUSTAINABILITY ISSUES

ISSN 2345-0282 (online) http://jssidoi.org/jesi/

2020 Volume 7 Number 3 (March)

http://doi.org/10.9770/jesi.2020.6.3(43)

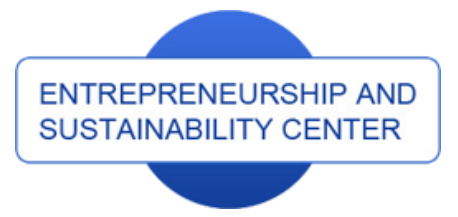

Publisher

http://jssidoi.org/esc/home

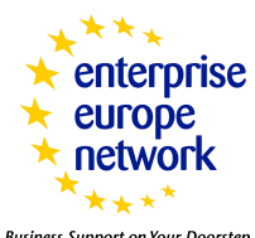

Business Support on Your Doorstep

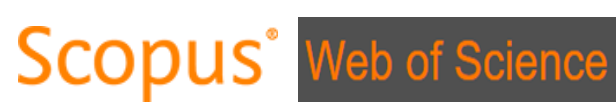

\author{
thes
}

(1)
(1)

\begin{abstract}
Clarivate
Analytics
\end{abstract}
\title{
EFFICIENCY OF THE PUBLIC FINANCIAL SUPPORT GRANTED TO SOCIAL ENTERPRISES*
}

\author{
Marian Oliński \\ University of Warmia and Mazury in Olsztyn, Oczapowskiego 2, 10-719 Olsztyn, Poland \\ E-mail: olinski@uwm.edu.pl
}

Received 12 August 2019; accepted 10 January 2020; published 30 March 2020

\begin{abstract}
The paper deals with investigating analysis that reveals the efficiency of financial support received by social enterprises. Recently, this specific type of enterprise has been gaining more and more interest among managers and scientists. Some of them even noted that the social enterprise can be considered as a business of the future. Nevertheless, the key to the successful functioning on the market and development of this kind of enterprises is the financial support. One of the sources of obtaining financial support by social enterprises are public funds from EU assistance programs. However, these funds should be used effectively, because they are public property and therefore belong to all citizens (taxpayers). Therefore, in addition to the formal requirements set out in individual European Union aid actions focusing mainly on social goals, a traditional approach to assessing the efficiency of investments focusing on the business goals of the capital donor is also needed. Thus, the purpose of the study was to assess the efficiency of financial support granted to social enterprises. Efficiency was examined in a traditional way as the ratio of financial benefits obtained by the state thanks to granting support in relation to the financial costs spent on this support. The subject of the study consisted of 22 social enterprises of various forms (social cooperatives, associations, foundations) from the Warmian-Mazurian region, which received financial support in 2017-2018. The results show that a significant amount of money invested by the state to help in the formation and functioning of social enterprises is returned to the state budget.
\end{abstract}

Keywords: social enterprise; financial support; efficiency

Reference to this paper should be made as follows: Oliński, M. 2020. Efficiency of the public financial support granted to social enterprises. Entrepreneurship and Sustainability Issues, 2095-2108. https://doi.org/10.9770/jesi.2020.7.3(43)

*The publication was written as a result of the author's internship at Edinburgh Napier University, co-financed by the European Union under the European Social Fund (Operational Program Knowledge Education Development), carried out in the project Development Program at the University of Warmia and Mazury in Olsztyn (POWR.03.05. 00-00-Z310/17)
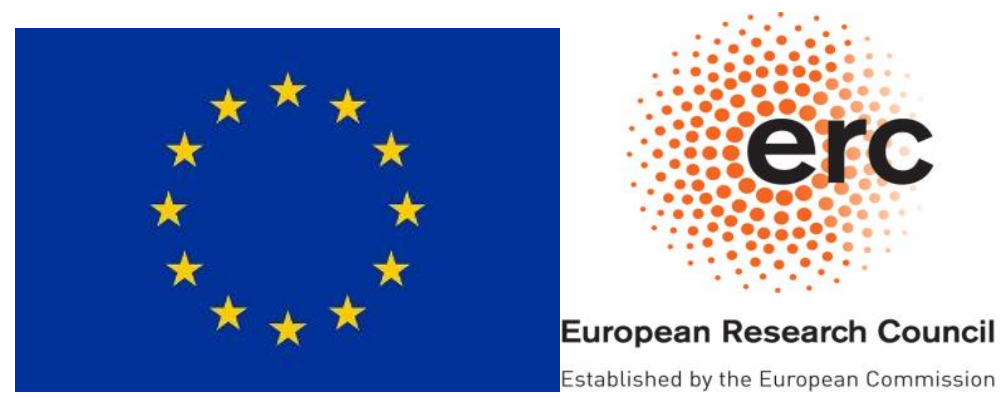
ENTREPRENEURSHIP AND SUSTAINABILITY ISSUES

ISSN 2345-0282 (online) http://jssidoi.org/jesi/

2020 Volume 7 Number 3 (March)

http://doi.org/10.9770/jesi.2020.7.3(43)

JEL Classifications: D20, L31, M10

\section{Introduction}

Social enterprises can tackle a wide range of social and environmental issues and operate in all parts of the economy (Defourny, Nyssens, 2008, p.205). Some people lack skills and knowledge, or are disadvantaged to successfully get a job in a competitive labour market (Potluka, 2017, p.5). Most often they are long-term unemployed and disabled (not only physically but also mentally).

Studying social enterprise has theoretical and practical benefits for scholars in the fields of economics and entrepreneurship. For economists, social enterprises represent evidence of an alternative to state and private market approaches to economic development (Ridley-Duff, 2015, p.44). This paper fits into this research area, but points out that the stimulation of socio-economic development should be rational and effective. In particular, support providers should be interested in efficiency, regardless of whether it is a private or public capital donor. However, in order to assess the efficiency of supporting social enterprises from public funds, it is necessary to develop appropriate methods and measurement tools. Therefore, the purpose of the paper was to assess the efficiency of financial support granted to social enterprises according to the developed proprietary methodology.

The company needs an initial financial assistance or support and social enterprise is no exception. In most cases, it is necessary to fund throughout operations, since the main goal is to create social value (Akbulaev, Aliyev, Ahmadov, 2019, p.3). Nevertheless, creation of social value should also be considered from the point of view of economic efficiency.

The structure of the article is as follows: the theoretical part presents the concept related to the idea of a social enterprise. It presents controversy regarding the definition of a social enterprise, as well as a consensus developed regarding the recognition of the dual nature of this type of enterprise (already at the definition level). Then the theoretical approach to efficiency was presented, emphasizing the meaning of the term in the context of the public sector and the spending of public funds. Both theoretical parts have been kept to a minimum due to the existence of extensive literature on both issues. Then, research methodology was presented, in which the purpose and research question were presented. The description of the research sample and the research methods used are also presented here. Then, the results were presented, which was limited to presenting the obtained results, while their interpretation was included in the discusion part. The whole article is summarized in the conclusions, in which also the research limitations are presented.

\section{The theory of a social enterprise}

Social enterprise is a concept which has different meanings across countries and regions. Nevertheless, the concept of social enterprise almost always combines two attributes: "entrepreneurship" and "sociality". The first of them indicates that it is about an organization that conducts business activity, and thus produces products or services, combining available material and intellectual resources in a way that creates added value, i.e. economic surplus. In turn, the attribute "sociality" indicates on the one hand the basic resources that the company uses, and on the other its mission. When it comes to resources, the essence lies in relying on social capital shaped within a particular local community. In relation to the mission, the basic thing is that the company's operation is focused on social integration on the scale of a given local community, and from another perspective, its main goal is to counteract social exclusion through professional and economic activation. The term social enterprise itself was introduced to distinguish new entrepreneurial activities from the traditional third sector [Bacchiega, Borzaga 2003, s. 27]. 
The target (ideal) model that should characterize a social enterprise has also been introduced. For example, according to EMES the defining characteristics of the social enterprise "ideal type" include:

1. A continuous activity producing goods and/or selling services (economic dimension),

2. A high degree of autonomy (economic dimension),

3. A significant level of economic risk (economic dimension),

4. A minimum amount of paid work (economic dimension),

5. An explicit aim to benefit the community (social dimension),

6. An initiative launched by a group of citizens (social dimension),

7. A decision-making power not based on capital ownership (social dimension),

8. A participatory nature, which involves the persons affected by the activity (social dimension),

9. Limited profit distribution (social dimension) (Defourny, Nyssens, 2010, p. 12).

The easiest way, however, is to define a social enterprise as an organization trying to apply business solutions to social problems (Thompson, Doherty, 2006, p. 361). This approach is indicated by 10 sample definitions presented in Table 1.

Table 1. Definitions of social enterprise

\begin{tabular}{|c|l|l|}
\hline $\mathrm{Nr}$ & \multicolumn{1}{|c|}{ Definition } & \multicolumn{1}{|c|}{ Authors } \\
\hline 1. & $\begin{array}{l}\text { Organisation with an overarching core social mission funded through market-based } \\
\text { initiatives }\end{array}$ & $\begin{array}{l}\text { M.P. Miles, M.L. Verreynne and B. Luke } \\
(2014, \text { p. 550). }\end{array}$ \\
\hline 2. & $\begin{array}{l}\text { Ordinary commercial entity that generate income through the exchange of goods and } \\
\text { services, but operate with the added social objective of providing work opportunities to } \\
\text { people who have experienced persistent difficulties finding or maintaining employment }\end{array}$ & A. Chan (2016, p. 1719-1720). \\
\hline 3. & Organisation that pursues a social mission through the use of market mechanisms & V. Pestoff and L. Hulga (2015, p. 1752). \\
\hline 4. & $\begin{array}{l}\text { A kind of business model which meets both social and economic objectives, } \\
\text { contributing to labour market integration and social cohesion. }\end{array}$ & Y.Ch Cho and Jang (2014, p. 119). \\
\hline 5. & $\begin{array}{l}\text { complex social issues because they combine the efficiency and resources of the } \\
\text { traditional business model with the sense of mission of the charity one }\end{array}$ & T. Ramus and A. Vaccaro (2017, p. 307). \\
\hline 6. & $\begin{array}{l}\text { Private organization that typically pursue goals other than profit: its main purpose is } \\
\text { not to generate financial gains for their owners or stakeholders but to provide goods and } \\
\text { services either to their members or to the community at large }\end{array}$ & D. Staicu (2018, p.909). \\
\hline 7. & $\begin{array}{l}\text { Organization which places a high value on its independence and on economic risk- } \\
\text { taking related to ongoing socio-economic activity. }\end{array}$ & European Research Network (2013). \\
\hline 8. & $\begin{array}{l}\text { Business with primarily social objectives whose surpluses are principally reinvested for } \\
\text { that purpose in the business or in the community, rather than being driven by the need to } \\
\text { maximize profit for shareholders and owners }\end{array}$ & $\begin{array}{l}\text { Department of Trade and Industry } \\
\text { (2002). }\end{array}$ \\
\hline 9. & $\begin{array}{l}\text { Organization with dual-purpose businesses that mediate profit goals with social } \\
\text { objectives. }\end{array}$ & Kerlin J.A. (2006, p.248). \\
\hline 10. & $\begin{array}{l}\text { Private, autonomous institution that is engaged in the supply of services and goods } \\
\text { with a merit or general-interest nature in a stable and continuous way. }\end{array}$ & G. Galera, C. Borzaga (2009, p.215). \\
\hline
\end{tabular}
Source: composed by author according to the literature indicated in the table

Summarizing, scholars have yet to agree a universal and distinctive definition of social enterprise. The profusion of definitions found in the first decade of the twenty-first century is gradually giving way to an emerging consensus that the aim of social enterprise is to achieve economic, social and environmental value by trading for a social purpose (Haugh, 2012, p.9). This consensus is indicated by the definitions presented in Table 1. Therefore, in the research part and the interpretation of the results, the dual nature of such enterprises was also taken into account. 


\section{ENTREPRENEURSHIP AND SUSTAINABILITY ISSUES}

ISSN 2345-0282 (online) http://jssidoi.org/jesi/

2020 Volume 7 Number 3 (March)

http://doi.org/10.9770/jesi.2020.7.3(43)

\section{Efficiency of the public support - theoretical approach}

Effectiveness and efficiency are exclusive performance measures, which entities can use to assess their performance. Efficiency is oriented towards successful input transformation into outputs, where effectiveness measures how outputs interact with the economic and social environment (Bartuševičienè, Šakalytė, 2013, p.41). Representatives of management sciences place great emphasis on linking the concept of economic efficiency with the principles of rational operation and principle of economical production. The principle of economical production is appropriate for every business entity - this also applies to social enterprises. This entity may strive to achieve a given objective with minimal use of resources, or may strive to maximize the objective with pre-defined measures. It may also choose intermediate routes between maximizing the goal and minimizing the means - but in each case we are dealing with the implementation of the principle of economical production. There are two basic reasons for the link between the principle of economical production and economic efficiency. First of all, a close connection (especially visible in the field of management sciences) of efficiency with the issue of defining and achieving the organization's goals. Secondly, the inclusion of two basic categories in the process of achieving these goals, namely effects and outlays. Therefore, most definitions of economic efficiency are specified as the relation of a particular effect to a given factor of production or a set of factors of production (Matwiejczuk, 2000, p.27). If we add to these two quantities the fact that everything must take place and be assessed in a given time, it can be stated that the economic effectiveness of development processes is determined by three components: inputs, effects and time (Wesołowski, 1996, p. 133). From this perspective, the scientific research presented in the empirical part of the paper was carried out.

The high visibility of social enterprise in academic, practice and policy circles has created a vibrant arena for theory testing, advances and development (Haugh, 2012, p.7). One of such arenas is the issue of efficiency in supporting social enterprises. Efficiency is a term used in both colloquial and scientific language (especially in the field of economic sciences). While the colloquial application does not require strict operationalization of this concept, its use in economic and social practice requires not only the precise definition of the concept of efficiency, but also the construction of methods and tools for measuring this efficiency. Although social enterprises integrate the economic and social dimensions in their activities, efficiency is only one of the parameters that can assess the functioning of these organizations, but often in relation to such enterprises there is a situation in which public funds are distributed, and therefore measures belonging to the general public, which is an argument in favor of giving the greatest importance to the issue of efficiency. Proper measurement of the value of effects forces the scientist to capture the quantity and quality of goods and services produced. In the private sector, a market mechanism allows this (price level determines the value of effects). In the public sector, in which a significant part of the goods and services produced is distributed outside the market mechanism, this seems much more difficult (Przygodzka, 2008, p. 162). In this perspective, building appropriate tools to monitor social efficiency should be a safeguard against waste of resources.

\section{The research methodology}

In the course of the study, general scientific research methods were used such as methods of deduction and induction, comparative analysis and synthesis, as well as method of scientific review of the source bases.

The main objective of the study was to assess the efficiency of financial support granted to social enterprises. This assessment was made on the basis of expenditure spent on establishing new or supporting existing social enterprises. Therefore, the main research question was: What impact on the state of public finances was caused by providing support to the surveyed enterprises?

The first phase of the research involved the examination of the concept of social enterprise and efficiency of the public support. The second phase included selection of social enterprises for research (the sample selection was 
deliberate, not random). The next phase included the analysis of project documentation, financial documentation of the surveyed enterprises and determination of the economic situation of all employees employed in social enterprises (Figure 1).

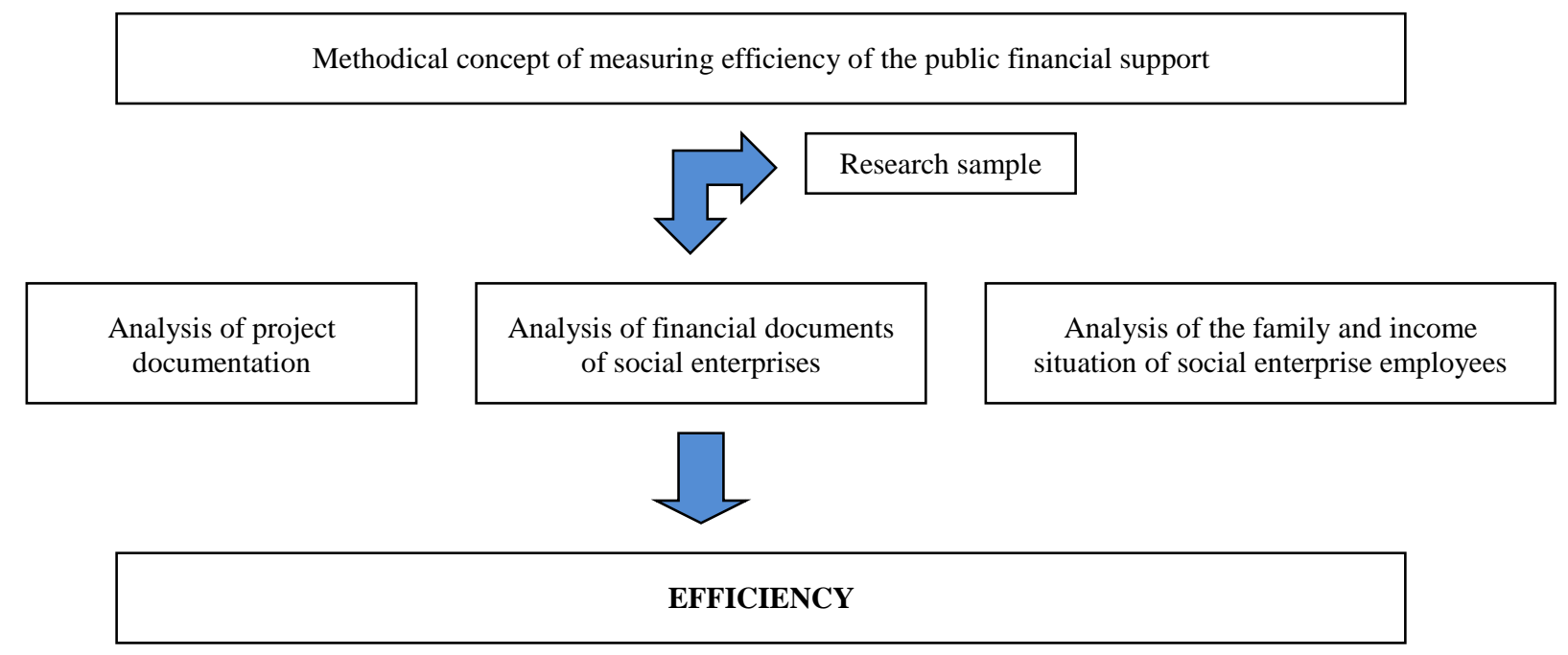

Fig. 1. The research model

Source: composed by author

The research covered social enterprises operating in Warmia and Mazury. It is a region located in the northeastern part of Poland, whose characteristic feature is the high level of unemployment (in relation to the national average). It covers $7.7 \%$ of Poland $\left(24,173.47 \mathrm{~km}^{2}\right)$. According to the list published by Department of Social Economy and Public Benefit Ministry of Labor and Social Policy, in July 2019 there were 79 enterprises (http://www.ekonomiaspoleczna.gov.pl/). In the Olsztyn subregion (it includes the Bartoszycki, Kętrzyński, Lidzbarski, Mrągowski, Nidzicki, Olsztyn, Szczycieński poviats) and the city of Olsztyn (which is treated as a separate subregion - the capital of Warmia and Mazury), there were 22 entities that received support in 2017-2018 from the Social Economy Support Center in Olsztyn. The characteristics of these entities are presented in Table 2.

Table 2. Characteristics of the surveyed social enterprises

\begin{tabular}{|c|l|l|}
\hline $\mathrm{Nr}$ & \multicolumn{1}{|c|}{ Legal form } & \multicolumn{1}{c|}{ Buissness description } \\
\hline 1 & association & $\begin{array}{l}\text { Book publishing, newspaper and magazine publishing, newspaper printing, other printing, bookbinding } \\
\text { and related services. }\end{array}$ \\
\hline 2 & social cooperative & Sound system and comprehensive service of artistic events. \\
\hline 3 & social cooperative & Motorcycle workshop and commission; occasional transport. \\
\hline 4 & association & Running a restaurant, retail sale in non-specialized stores with a predominance of food and drink. \\
\hline 5 & association & $\begin{array}{l}\text { Artistic and cultural activities directed at supporting youth activity and combating social exclusion } \\
\text { among youth. }\end{array}$ \\
\hline 6 & social cooperative & $\begin{array}{l}\text { Manufacture of ready meals and dishes; preparation and delivery of food for external recipients; other } \\
\text { food service activities. }\end{array}$ \\
\hline 7 & foundation & $\begin{array}{l}\text { Propagating stress urinary incontinence treatment with innovative, minimally invasive methods, } \\
\text { including by laser method. }\end{array}$ \\
\hline 8 & foundation & Activities supporting insurance and pension funds \\
\hline 9 & foundation & Emergency medical services; education and training: prevention of a healthy lifestyle. \\
\hline 10 & social cooperative & Activities connected with the production of films, video recordings and television programs. \\
\hline 11 & foundation & $\begin{array}{l}\text { Production of radio and television programs as well as spots and advertising films; running regional } \\
\text { internet television. }\end{array}$ \\
\hline 12 & social cooperative & Preparation and delivery of food for external recipients; production of ready meals and dishes. \\
\hline
\end{tabular}




\begin{tabular}{|c|l|l|}
\hline 13 & social cooperative & $\begin{array}{l}\text { Activities of physiotherapists: physiotherapeutic diagnostics, physical therapy, hydrotherapy, } \\
\text { therapeutic massage, exercise therapy, etc.; non-school forms of sport education as well as sport and } \\
\text { recreational activities. }\end{array}$ \\
\hline 14 & association & Windsurfing and kitesurfing school, organizing sports colonies for young people. \\
\hline 15 & foundation & $\begin{array}{l}\text { Maintenance and repair of motor vehicles, except motorcycles; non-specialized cleaning of buildings } \\
\text { and industrial facilities. }\end{array}$ \\
\hline 16 & foundation & $\begin{array}{l}\text { Educational support activities, activities related to the performance of artistic performances, activities } \\
\text { related to the production of films, video recordings and television programs, photographic services. }\end{array}$ \\
\hline 17 & social cooperative & Activities related to the performance of artistic performances; catering. \\
\hline 18 & foundation & $\begin{array}{l}\text { Activities in the areas of broadly understood information technology; running an internet portal - an } \\
\text { innovative land property classifieds site. }\end{array}$ \\
\hline 19 & association & Furniture production, retail and wholesale of furniture. \\
\hline 20 & social cooperative & The production of candles and other products complies with ecological standards. \\
\hline 21 & association & $\begin{array}{l}\text { Renting and leasing of recreational and sports equipment; non-school forms of sport education and } \\
\text { sports and recreational activities; other sport-related activities. }\end{array}$ \\
\hline 22 & social cooperative & $\begin{array}{l}\text { Renting and leasing of recreational and sports equipment; repair of sports equipment; organization of } \\
\text { sporting events. }\end{array}$ \\
\hline
\end{tabular}

Source: composed by author according to project documentation

As can be seen, the surveyed entities took three legal forms typical for social enterprises: a social cooperative, foundation and association. On the other hand, the types of economic activity were various. There was no clear dominance of any of the sectors.

Another problem is setting an upper limit for the efficiency of using public funds. Of course, the reimbursement for enterprises paid to the public sector could exceed the amount of support granted to them (this has happened in the case of one enterprise - see results section). In addition, the key period is the period of operation of enterprises after receiving support and the related time interval in which the efficiency of assistance is assessed. Therefore, the level of 50\% efficiency calculated as the ratio of reimbursement to the level of support provided is an appropriate demarcation line between poor and good result. Statistics have also adopted this way of reasoning, in which the level of 0.5 (or 50\%) is often a demarcation line that allows interpreting specific phenomena (patrz np. Aczel, 2008, p.441; Fernandes, 2009, p.127). Therefore, adopting the reasoning that a return of public funds invested in social enterprises in the amount of minimum 50\% would be a beneficial phenomenon (Figure 2).

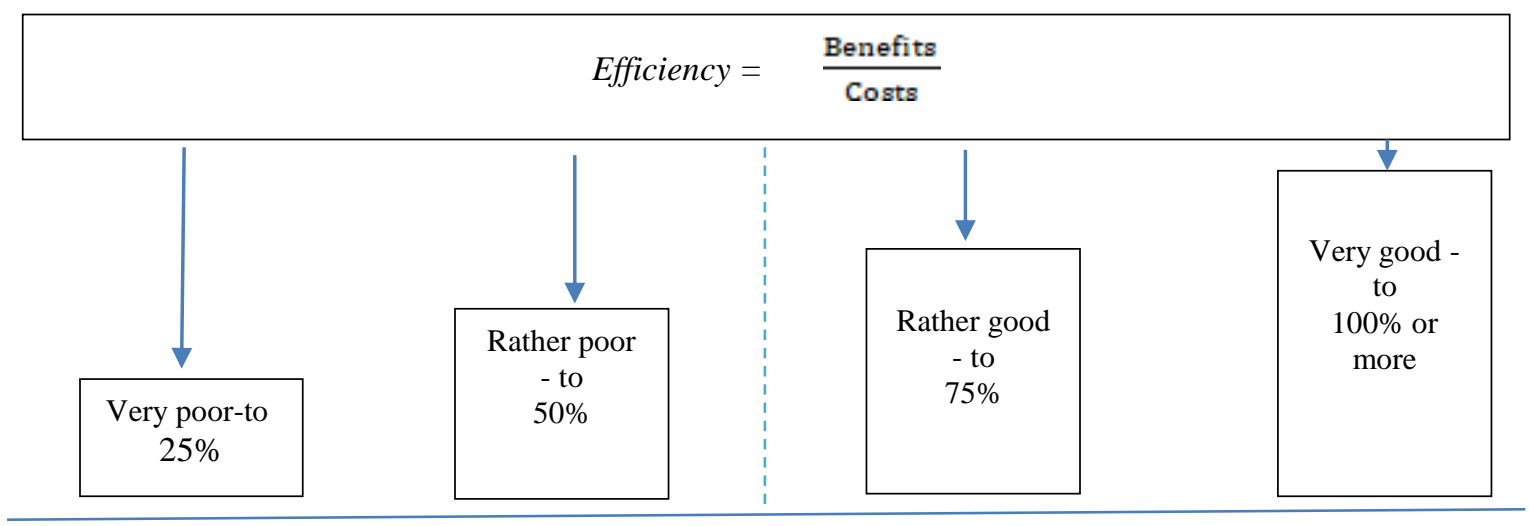

Fig. 2. Thresholds for assessing efficiency of the public financial support Source: composed by author

It should be remembered that the social economy sector is being dealt with all its conditions. Therefore, the 50\%$100 \%$ return on public funds invested is very beneficial, assuming the achievement of social goals, which are often difficult to express with economic effects (e.g. joy of a person who has a job, stability in the family, sense of meaning in life, etc.). In addition, commercial investors should be interested in returns exceeding $100 \%$ of the 


\section{ENTREPRENEURSHIP AND SUSTAINABILITY ISSUES}

ISSN 2345-0282 (online) http://jssidoi.org/jesi/

2020 Volume 7 Number 3 (March)

http://doi.org/10.9770/jesi.2020.7.3(43)

capital invested and there would be no need for intervention in the form of public support. If it is necessary, it results from the specifics of social entrepreneurship and an attempt to activate socially excluded people.

Estimates presented in the results section and discussion are presented in the Polish currency - PLN (about 4.3 PLN = 1 EURO).

\section{Results}

The analyzed social enterprises received the total amount of PLN 3538077.00 under direct financial support. In the form of investment support (i.e. funds transferred, which had to be spent on investments in these enterprises), PLN 2038299.70 was transferred. In turn, basic operational support (so called "bridge financing" - it did not have to be of an investment nature) was PLN 920 033.24, while extended bridge financing (granted in specific cases) was PLN 579744.06 (table 3). It can be seen that the main intention of the analyzed financial support was to stimulate investment in social enterprises, and thus to cause their qualitative development and sustainability (investment support constituted 58\% of the total support provided to social enterprises).

Bridging financing, i.e. operational support, decreased over time (extended support was almost $40 \%$ smaller than basic support). It follows that the policy of supporting social enterprises was aimed at gradually gaining independence, so that in the future they could compete on classical terms (i.e. on market principles without financial support).

Table 3. Public support for social enterprise

\begin{tabular}{|c|c|c|c|c|c|c|}
\hline $\begin{array}{c}\text { Enterprises } \\
\text { code }\end{array}$ & $\begin{array}{c}\text { Date of starting } \\
\text { business } \\
\text { activity }\end{array}$ & $\begin{array}{c}\text { Date of signing } \\
\text { the support } \\
\text { contract }\end{array}$ & $\begin{array}{c}\text { Investment } \\
\text { subsidy } \\
\text { amount }\end{array}$ & $\begin{array}{c}\text { Amount of } \\
\text { bridging } \\
\text { financing }\end{array}$ & $\begin{array}{c}\text { Amount of } \\
\text { extended bridging } \\
\text { financing }\end{array}$ & $\begin{array}{c}\text { Total support } \\
\text { amount }\end{array}$ \\
\hline 1 & $23-12-2005$ & $07-06-2018$ & 119400.00 & 55139.97 & 37284.37 & 211824.34 \\
\hline 2 & $30-12-2005$ & $02-08-2018$ & 48000.00 & 22040.75 & 14907.82 & 84948.57 \\
\hline 3 & $10-03-2006$ & $27-11-2017$ & 120000.00 & 55372.19 & 37298.30 & 212670.49 \\
\hline 4 & $24-04-2008$ & $25-07-2017$ & 48000.00 & 22144.38 & 14907.99 & 85052.37 \\
\hline 5 & $11-05-2009$ & $25-09-2017$ & 120000.00 & 55378.63 & 37253.85 & 212632.48 \\
\hline 6 & $18-09-2012$ & $05-02-2018$ & 24000.00 & 11010.85 & 5972.38 & 40983.23 \\
\hline 7 & $12-12-2012$ & $29-06-2017$ & 120000.00 & 55142.35 & 37411.63 & 212553.98 \\
\hline 8 & $05-11-2013$ & $05-12-2017$ & 120000.00 & 47992.46 & 37285.44 & 205277.90 \\
\hline 9 & $04-02-2014$ & $23-06-2017$ & 120000.00 & 55142.35 & 37328.89 & 212471.24 \\
\hline 10 & $19-02-2014$ & $23-06-2017$ & 96000.00 & 44113.88 & 29863.12 & 169977.00 \\
\hline 11 & $04-03-2015$ & $04-12-2017$ & 95980.00 & 44104.99 & 29835.04 & 169920.03 \\
\hline 12 & $24-06-2015$ & $11-01-2018$ & 24000.00 & 11027.37 & 7455.98 & 42483.35 \\
\hline 13 & $12-11-2015$ & $17-11-2017$ & 110000.00 & 55140.80 & 34318.68 & 199459.48 \\
\hline 14 & $10-04-2017$ & $21-12-2017$ & 120000.00 & 33078.29 & 11072.07 & 164150.36 \\
\hline 15 & $05-09-2017$ & $05-10-2017$ & 120000.00 & 55130.48 & 37284.59 & 212415.07 \\
\hline 16 & $28-09-2017$ & $24-11-2017$ & 105000.00 & 55372.19 & 37285.44 & 197657.63 \\
\hline 17 & $22-11-2017$ & $30-11-2017$ & 72000.00 & 33226.70 & 22371.26 & 127597.96 \\
\hline 18 & $11-12-2017$ & $18-01-2018$ & 96000.00 & 44109.47 & 10557.81 & 150667.28 \\
\hline 19 & $29-12-2017$ & $28-02-2018$ & 96000.00 & 44092.93 & 17937.31 & 158030.24 \\
\hline 20 & $23-01-2018$ & $23-08-2018$ & 48000.00 & 22054.10 & 14909.11 & 84963.21 \\
\hline 21 & $27-03-2018$ & $26-04-2018$ & 119919.70 & 55110.63 & 37340.04 & 212370.37 \\
\hline 22 & $28-06-2018$ & $06-07-2018$ & 96000.00 & 44107.48 & 29862.94 & 169970.42 \\
\hline Total & $\mathrm{X}$ & $\mathrm{X}$ & $\mathbf{2 0 3 8 2 9 9 . 7 0}$ & $\mathbf{9 2 0 0 3 3 . 2 4}$ & $\mathbf{5 7 9 7 4 4 . 0 6}$ & $\mathbf{3 5 3 8 0 7 7 . 0 0}$ \\
\hline
\end{tabular}

Source: composed by author according to project documentation and financial statements of social enterprises

The effects of the support provided are presented in Table 4. The supported enterprises generated a total of PLN 772229.67 before granting the support and PLN 2021400.60 after receiving the support. No specific dates can be given here, as revenues before receiving support were set at the end of the year preceding the support (so it was 2016 or 2017 depending on the date of signing the contract, and hence the date of transferring funds). On the 


\section{ENTREPRENEURSHIP AND SUSTAINABILITY ISSUES}

ISSN 2345-0282 (online) http://jssidoi.org/jesi/

2020 Volume 7 Number 3 (March)

http://doi.org/10.9770/jesi.2020.7.3(43)

other hand, revenues after receiving support were analyzed after a full year (i.e. 12 months) after receiving support (so it was in 2018 or 2019 - depending on the receipt of support). The penultimate column from Table 4 includes payments made to the public sector in the form of contributions to the Social Insurance Institution (pension system), as well as taxes and public levies (Value Added Tax - VAT, income tax paid from employed persons - i.e. Personal Income Tax - PIT or Corporate Income Tax - CIT).

Table 4. Effects of support received among the surveyed enterprises

\begin{tabular}{|c|c|c|c|c|c|}
\hline $\begin{array}{l}\text { Enterprises } \\
\text { code }\end{array}$ & $\begin{array}{c}\text { Total } \\
\text { support } \\
\text { amount }\end{array}$ & $\begin{array}{l}\text { The company's } \\
\text { revenues before the } \\
\text { granting of funds }\end{array}$ & $\begin{array}{l}\text { Revenue after } \\
\text { receiving aid }\end{array}$ & $\begin{array}{l}\text { Contributions to the } \\
\text { public sector }\end{array}$ & $\begin{array}{l}\text { Persons employed as a } \\
\text { consequence of support }\end{array}$ \\
\hline 1 & 211824.34 & 0.00 & 5500.00 & 37475.00 & 5 \\
\hline 2 & 84948.57 & 0.00 & 19542.00 & 10241.05 & 2 \\
\hline 3 & 212670.49 & 0.00 & 149387.48 & 23617.09 & 5 \\
\hline 4 & 85052.37 & 171034.17 & 444771.31 & 14402.05 & 2 \\
\hline 5 & 212632.48 & 19395.00 & 107826.80 & 362152.50 & 5 \\
\hline 6 & 40983.23 & 103396.66 & 248007.62 & 8648.47 & 1 \\
\hline 7 & 212553.98 & 0.00 & 28090.32 & 20127.67 & 5 \\
\hline 8 & 205277.90 & 76518.46 & 99675.42 & 19726.56 & 5 \\
\hline 9 & 212471.24 & 67793.83 & 143328.29 & 25309.01 & 5 \\
\hline 10 & 169977.00 & 51657.00 & 68996.50 & 20482.97 & 4 \\
\hline 11 & 169920.03 & 273374.55 & 259841.22 & 19641.73 & 4 \\
\hline 12 & 42483.35 & 9060 & 105825 & 4659.75 & 1 \\
\hline 13 & 199459.48 & 0.00 & 5500 & 37954.53 & 5 \\
\hline 14 & 164150.36 & 0.00 & 0.00 & 26308.26 & 5 \\
\hline 15 & 212415.07 & 0.00 & 0.00 & 187462.24 & 5 \\
\hline 16 & 197657.63 & 0.00 & 0.00 & 28739.09 & 5 \\
\hline 17 & 127597.96 & 0.00 & 8856.00 & 15408.35 & 3 \\
\hline 18 & 150667.28 & 0.00 & 25470.00 & 18348.16 & 4 \\
\hline 19 & 158030.24 & 0.00 & 238732.93 & 18394.15 & 4 \\
\hline 20 & 84963.21 & 0.00 & 12488.00 & 8556.25 & 2 \\
\hline 21 & 212370.37 & 0.00 & 23731.71 & 31578.69 & 5 \\
\hline 22 & 169970.42 & 0.00 & 25830.00 & 17005.01 & 4 \\
\hline Total & 3538077.00 & 772229.67 & 2021400.60 & 956238.59 & 86 \\
\hline
\end{tabular}

Source: composed by author according to project documentation and financial statements of social enterprises

Generally, one year after receiving support, the economic results of enterprises improved over 2.5 times (262\%). However, determining the net effect requires taking into account the dynamic development of the Polish economy in recent years.

Therefore, the results obtained by enterprises No. 1-13 from Table 4 need to be corrected. These enterprises already existed before. So they would generate some income without getting support. On the other hand, enterprises No. 14-22 were created as a consequence of the possibility of obtaining support (the founders of these enterprises were recruited for the support program and expressed the opinion that without help they would not dare to become social entrepreneurs).

Therefore, the problem of correcting the obtained values should be solved for the first 13 companies. Most of them received support in 2017 (9 out of 13 entities, including 3 entities that signed the agreement in 2018 are they are not VAT payers). Therefore, the growth of the economy should be analyzed, or rather the growth of revenues of microenterprises (supported enterprises analyzed in this article belong to the category of microenterprises) in 2018 compared to 2017. According to the Central Statistical Office in 2018, enterprises employing up to 9 people obtained PLN 1323.6 billion in total revenues (which means an increase of 17.9\% year-on-year). At the same time, costs in 2018 in enterprises employing up to 9 people amounted to PLN 1149.2 billion, i.e. 17.1\% higher than a year ago (https://stat.gov.pl). Given the complexity of VAT, it is difficult to clearly determine what effect 


\section{ENTREPRENEURSHIP AND SUSTAINABILITY ISSUES}

ISSN 2345-0282 (online) http://jssidoi.org/jesi/

2020 Volume 7 Number 3 (March)

http://doi.org/10.9770/jesi.2020.7.3(43)

of the increase in VAT paid was caused by these increases in revenues and costs. Approximately $1 \%$ effect can be assumed in the form of a slightly higher increase in revenues over costs. The analyzed enterprises paid a total of PLN 40 640.40 VAT. On the other hand, adjusting the net effect in question for the first 13 companies would change the estimates by approximately PLN 7036.94 (this is 1\% of the total amount of tax 703693.73 that these companies paid). So this is a low amount that will change the effect of paid VAT from just PLN 406640.40 to PLN 399 603.46. With regard to corporate income tax, the situation is slightly different, as the Central Statistical Office of Poland stated that the financial result of non-financial enterprises employing up to 9 people amounted to PLN 174.5 billion in 2018 and was higher by $23.1 \%$ per year (https://stat.gov.pl). Income tax revenues of the 13 enterprises analyzed should therefore be reduced by $23.1 \%$ as an effect not caused by the support provided but by the development of the Polish economy. This is a large percentage, but the income tax paid by supported social enterprises was very low. In total, the analyzed enterprises paid PLN 35,188.00 in income tax (and 13 enterprises separated out only PLN 24 990.00). This is due to the low gross profit achieved by these enterprises and the construction of the tax system and the possibility of allocating the generated profit for statutory purposes (without paying tax). Therefore, taking into account the substantial percentage increase in profit among Polish microenterprises translates in the analyzed case only by a correction of PLN 5772.69 (PLN $24990.00 * 23.1 \%$ ). You should not adjust income tax contributions from individuals (employees), as well as contributions to the pension system. They are high in Poland, but the employees employed as part of the support received were the long-term unemployed and/or disabled (formal support requirements), therefore finding a work on market conditions by them (i.e. without any support from this title for the employer) was unlikely.

To sum up, the financial effect for the national budget in the form of levies and taxes paid to the Treasury amounted to PLN 956 238.59, which is $27 \%$ of the total public funds allocated to supporting enterprises. Taking into account the aforementioned net effects (and thus the improvement of the financial results of Polish microenterprises in this period), this percentage would be slightly over $26 \%$. Thus, according to Figure 2 , these effects do not change the classification of the efficiency rating (rather poor). In addition, taking into account all the effects (beneficial and unfavorable to public finances), it should be added to the benefits that many people employed thanks to support did not have to pay benefits through social assistance centers (while they were unemployed for more than a year so unemployment benefit, which can be taken for a maximum of 1 year). Pursuant to the Act of 12 March 2004 on social assistance (Journal of Laws of 2019, item 1507), some people are entitled to a temporary or permanent benefit.

The amount of the temporary benefit depends on whether the person is a lonely person or not, while the permanent benefit is intended for disabled people. In addition, their income (or average family income) may not exceed a certain monthly level, e.g. for a single person - PLN 701, while for a family member - PLN 528.The algorithms for calculating the amount of benefit vary depending on the specific situation (i.e. income, being lonely or disabled - Table 5). However, after calculations, it can be stated that the state budget saved a total of PLN 191544 by supporting the analyzed enterprises (in total, analysis of personal and material situation carried out among 86 persons indicated that 48 persons would be entitled to payment of benefits).

Table 5. Savings on unpaid benefits for employees in supported social enterprises

\begin{tabular}{|c|c|c|}
\hline Criterion & Calculation method & $\begin{array}{c}\text { Unpaid amount in PLN (benefit } \\
\text { of the public finance sector) }\end{array}$ \\
\hline Periodic benefit - a person in the family & $\begin{array}{c}{[(528 \text { PLN * number of people in the family) - }} \\
\text { total income } * 50 \%\end{array}$ & 51036 \\
\hline Periodic benefit - single person & (PLN 701 - income) $* 50 \%$ & 19036 \\
\hline Permanent benefit - a person in the family & PLN 528 - average income per family member & 96976 \\
\hline Permanent benefit - single person & 701 PLN - income (but not more than 604 PLN) & 24496 \\
\hline \multicolumn{2}{|c|}{ Total } & $\mathbf{1 9 1 5 4 4 ~ P L N ~}$ \\
\hline
\end{tabular}

Source: composed by author according to the Act of 12 March 2004 on social assistance 


\section{ENTREPRENEURSHIP AND SUSTAINABILITY ISSUES}

ISSN 2345-0282 (online) http://jssidoi.org/jesi/

2020 Volume 7 Number 3 (March)

http://doi.org/10.9770/jesi.2020.7.3(43)

Although this is not a direct payment to the state budget, it has allowed the public sector not to pay funds amounting to almost PLN 200 000. It should therefore be recognized on the financial benefit side of the public finance sector. In this case, after taking into account all variables (i.e. the net effect and the possibility of saving unpaid amounts from benefits), financial benefits for the public sector caused by the analyzed state intervention (granting support to socialenterprises) in the amount of PLN 1134972.96 (according to calculation: PLN 956238 can be attributed, due to corporate contributions minus PLN 7036.94 due to the net effect of VAT and minus PLN 5772.69 due to the net effect of income tax and plus PLN 191544 due to public funds saved on allowances). In total, this gives $32.1 \%$ savings or a refund to the public sector. This result is therefore more favorable than $26 \%-27 \%$, nevertheless it can be further assessed as rather poor, taking into account the interpretation presented in Figure 2.

\section{Discussion}

The analyzed enterprises were characterized by varied efficiency calculated according to the formula:

$$
\text { Efficiency }=100 \%
$$

Where Benefits are measured by financial contributions to the public sector and Costs are measured by public expenditure related to financial support directed to social enterprises.

Among enterprises, there were units that significantly exceeded the 50\% threshold in relation to the benefits they brought to the public sector in relation to the expenditures that the State budget incurred in the process of supporting them, but there were also those that did not exceed even 10\% (including all those described in the results effects). See Table 6.

\begin{tabular}{|c|c|c|c|c|c|c|c|c|c|c|c|}
\hline Enterprises code & 1 & 2 & 3 & 4 & 5 & 6 & 7 & 8 & 9 & 10 & 11 \\
\hline Efficiency (\%) & 17.69 & 12.06 & 11.11 & 16.93 & 170.32 & 21.10 & 9.47 & 9.61 & 11.91 & 12.05 & 11.56 \\
\hline Enterprises code & 12 & 13 & 14 & 15 & 16 & 17 & 18 & 19 & 20 & 21 & 22 \\
\hline Efficiency (\%) & 10.97 & 19.03 & 16.03 & 88.25 & 14.54 & 12.08 & 12.18 & 11.64 & 10.07 & 14.87 & 10.00 \\
\hline
\end{tabular}

Source: composed by author according to project documentation and financial statements of social enterprises

A desirable direction would therefore be to compare and thoroughly examine the differences between enterprises that achieved above-average results (and therefore very good from the point of view of the interpretation presented in Figure 2), and those that achieved very poor results. A thorough qualitative analysis of supported enterprises could perhaps outline some features that allow achieving above-average results regarding the effective use of support received (understood as above-average "repaying" to the public investor) and those features that interfere with the efficient use of public funds. The approach presented in this article regarding the efficiency of using public funds may arouse some controversy, however, it is difficult for it to refuse certain values of rationality. It should be remembered that the funds with which the analyzed enterprises were supported belong to the whole society. Therefore, if a decision was made to support enterprises from public funds, one should take care of their effective use and try to obtain a favorable return effect for the public finance sector, because in this way the common good is taken care of.

The period of assessing the effectiveness of public funds spent on the policy of supporting social entrepreneurship is debatable. In this type of purely commercial investment, the payback period lasts several years, and the assessment of the efficiency of the funds spent is also estimated at longer time intervals (e.g. several years).

The problem in the present case is, however, that several enterprises ceased to exist as soon as the project's lifetime ended, and even more entities went into "hibernation" (ie they generate no revenue). In addition, almost 


\section{ENTREPRENEURSHIP AND SUSTAINABILITY ISSUES}

ISSN 2345-0282 (online) http://jssidoi.org/jesi/

2020 Volume 7 Number 3 (March)

http://doi.org/10.9770/jesi.2020.7.3(43)

all enterprises did not extend employment to those who worked as a result of receiving support. However, those who are still working (it is only 6 people) are still co-financed from public funds (e.g. The State Fund for Rehabilitation of Disabled People). In this case, the shortening of the assessment period for the effeciency of public aid is the most justified. This problem has a broadly described theoretical background, because four main types of social enterprises have been identified in Europe - the characteristics of which are described in Table 7.

Table 7. Types of the social enterprises

\begin{tabular}{|c|c|c|}
\hline Lp. & $\begin{array}{c}\text { Type of the social } \\
\text { enterprise }\end{array}$ & Characteristics \\
\hline 1. & $\begin{array}{l}\text { Social enterprises } \\
\text { providing temporary } \\
\text { employment through } \\
\text { short-term subsidies }\end{array}$ & $\begin{array}{l}\text { The assumption of this model is to create for a given group of people opportunities to gain } \\
\text { professional experience (through temporary employment or to provide practical training in the } \\
\text { workplace), with a view to the future integration of employees in the open market. Examples of such } \\
\text { entities are Belgian workplace training organizations and Portuguese integration companies. In } \\
\text { Polish conditions, social integration centers and clubs as well as professional activity centers play } \\
\text { such a role. }\end{array}$ \\
\hline 2. & $\begin{array}{c}\text { Social enterprises } \\
\text { creating self-financing } \\
\text { target jobs }\end{array}$ & $\begin{array}{l}\text { Enterprises using this integration model seek to create jobs that are stable and economically } \\
\text { sustainable in the medium term. In the first stage, public subsidies are awarded to make up for the } \\
\text { difference in target group productivity. These subsidies are usually temporary and are phased out } \\
\text { once the entity is able to compete in the open labor market. After the subsidization stage, these } \\
\text { enterprises must provide integrated employees with remuneration from their own (mainly market) } \\
\text { resources. Examples are German and social companies and British local enterprises. In Poland, this } \\
\text { role can be played by social cooperatives, labor cooperatives, not-for-profit companies, non- } \\
\text { governmental organizations conducting business activity. }\end{array}$ \\
\hline 3. & $\begin{array}{c}\text { Social enterprises } \\
\text { based on permanently } \\
\text { subsidized employee } \\
\text { integration }\end{array}$ & $\begin{array}{l}\text { Enterprises using this model direct their activities to disadvantaged groups for whom integration in } \\
\text { the open labor market is difficult in the medium term. Therefore, permanent subsidies are created by } \\
\text { public institutions, stable jobs and certain types of enterprises protected against the open labor } \\
\text { market. Such companies employ people with disabilities, mental retardation and mental illness. } \\
\text { Examples of this type of entity are Portuguese, Swedish, Irish sheltered workshops and Belgian } \\
\text { professional adaptation enterprises. In Poland - occupational therapy workshops and sheltered } \\
\text { workshops. }\end{array}$ \\
\hline 4. & $\begin{array}{c}\text { Social enterprises } \\
\text { based on socialization } \\
\text { through productive } \\
\text { activity }\end{array}$ & $\begin{array}{l}\text { The goal of this group of enterprises is not professional integration on the labor market, but rather the } \\
\text { social rehabilitation and socialization of target groups through work focused on establishing and } \\
\text { maintaining social contacts, learning to respect the rules, leading a more structured lifestyle, etc. } \\
\text { Enterprises of this type direct their activities to people leaving addictions, people with significant } \\
\text { physical or mental disability. Examples of such entities are the French professional adaptation } \\
\text { centers and Belgian sheltered employment centers. In Poland, these are social integration clubs or } \\
\text { community self-help homes }\end{array}$ \\
\hline
\end{tabular}

Therefore, the problem of the national support policy is the fact that almost all the analyzed enterprises were of the first type (Table 7). On the other hand, the declared goals of the policy of supporting the social enterprise sector in Poland (declared even in program documents and draft guidelines) is the creation of the second type of enterprises, characterized in Table 7.

\section{Conclusion}

The paper presents an attempt at a "commercial" view on issues related to supporting social entrepreneurship. This approach may seem a bit surprising to many theoreticians dealing with the functioning of social enterprises. Nevertheless, it should be remembered that in the terms 'social economy', 'social enterprise' or 'social entrepreneurship', the word 'social' is only an adjective narrowing the field of scientific exploration. Social enterprises do not cease to be an enterprise with all its consequences, expressed in the need to compete in the market, struggle for limited resources and, above all, to acquire customers on more or less market terms. Therefore, although it should not be adopted in relation to the specific sector of social enterprises with $100 \%$ rules, measures and assessments of the classical sector of commercial enterprises, any monitoring and evaluation 


\section{ENTREPRENEURSHIP AND SUSTAINABILITY ISSUES}

ISSN 2345-0282 (online) http://jssidoi.org/jesi/

2020 Volume 7 Number 3 (March)

http://doi.org/10.9770/jesi.2020.7.3(43)

of their functioning should not be stopped. This may be expressed in the fact of adopting slightly modified values (e.g. satisfactory return of public funds amounting to less than 100\%), however, any measurement of effects and assessment of the efficiency of using public financial support should not be abandoned. Therefore, the result of the efficiency of spent funds at the level of $26 \%-31 \%$ (depending on whether or not specific effects are taken into account) can be considered as a poor, but not very poor. On the other hand, an improvement of this result by several percentage points would justify the awarding of a good grade in terms of the efficiency of using the received financial resources from public funds. The key to improving results is the sustainability of enterprises and created jobs. If it went beyond the minimum project requirements, and so if it were possible to move from the model of providing temporary employment through short-term subsidies to the model of creating self-financing, target jobs, this assessment would certainly be more favorable.

While I believe my findings and recommendations are important not only for the Polish sector of the social enterprises, I acknowledge the study's limitations. Mainly, the research sample was limited to just 22 units, which makes it difficult to generalize the conclusions. Therefore, this article should be treated as a proposal to undertake extensive research, even of an international nature. The difficulty here is the functioning of different legal regulations and different tax systems, however, after overcoming these problems, original research results could be obtained. In Poland, the lack of officially available data is a serious difficulty. While it is possible to check the amount of support received by specific entities, determining the effects of this support requires a lot of effort. This situation should be changed along the lines of other countries, especially since we are talking about effective control of the efficiency of spending public funds.

\section{References}

Act of 12 March 2004 on social assistance (Journal of Laws of 2019, item 1507). Available on the Internet: http://prawo.sejm.gov.pl/isap.nsf/download.xsp/WDU20040640593/U/D20040593Lj.pdf

Aczel, A. 2008. Business Statistics. Illinois, United States of America: McGraw-Hill Companies.

Akbulaev, N., Aliyev, Y., Ahmadov, T. 2019. Research models for financing social business: theory and practice, Heliyon, 5(5): 1-7. https://doi.org/10.1016/j.heliyon.2019.e01599

Bacchiega, A., Borzaga, C. 2003. The economics of the third sector: Toward a more comprehensive approach. In H. K. Anheier, A. BenNer (Eds.), The Study of The Nonprofit Enterprise: Theories And Approaches (pp. 27-48). Dordrecht, The Netherlands: Kluwer Academic/Plenum. Available on the Internet:

https://www.researchgate.net/publication/238116473_THE_ECONOMICS_OF_THE_THIRD_SECTOR_TOWARDS_A_MORE_COMP REHENSIVE_APPROACH1

Bartuševičienė, I., Šakalytė, E. 2013. Organizational Assessment: Effectiveness Vs. Efficiency. Social Transformations in Contemporary Society, 1: 45-53. Available on the Internet: http://stics.mruni.eu/wp-content/uploads/2013/06/45-53.pdf

Central Statistical Office of Poland - Data received form the Internet: https://stat.gov.pl

Chan, A. 2016. Personal Wellbeing of Participants of Social Purpose Enterprises: The Influence of Social Support. Voluntas: International Journal Of Voluntary \& Nonprofit Organizations, 27(4): 1718-1741. https://doi.org/10.1007/s11266-015-9637-4

Cho, Y.-Ch., Jang, J.-H. 2014. Analysis of Current Conditions Facing Social Enterprises in Korea: Policy Issues Regarding Their Sustainable Development. International Journal of Business and Social Research (IJBSR), 4(3): 119-125. http://dx.doi.org/10.18533/ijbsr.v4i3.460,https://thejournalofbusiness.org/index.php/site/article/view/460/349

Davister, C., Defourny, J., Gregoire, O. 2008. Vocational integration social enterprises (WISE) in the European Union: a category overview, in: J.J. Wygnański (eds.), Social enterprise. Anthology of key texts. Warsaw: The Foundation for Social and Economic Initiatives: 253-278. 


\section{ENTREPRENEURSHIP AND SUSTAINABILITY ISSUES}

ISSN 2345-0282 (online) http://jssidoi.org/jesi/

2020 Volume 7 Number 3 (March)

http://doi.org/10.9770/jesi.2020.7.3(43)

Defourny, J.; Nyssens, M. 2008. Social Enterprise in Europe: Recent Trends and Developments, Social Enterprise Journal, 4(3): 202- 228. Available on the Internet:

https://www.researchgate.net/publication/235299350_Social_enterprise_in_Europe_Recent_trends_and_developments

Defourny, J., Nyssens, M. 2010. Conceptions of social enterprise and social entrepreneurship in Europe and in the United States:

Convergences and divergences. Journal of Social Entrepreneurship, 1(1): 32-53. https://doi.org/10.1080/19420670903442053

Department of Trade and Industry. 2002. Social Enterprise. A Strategy for Success, Department of Trade and Industry, London, United

Kingdom, available on the Internet: www.dti.gov.uk/socialenterprise/strategy.htm

Department of Social Economy and Public Benefit Ministry of Labour and Social Policy - List of social enterprises -

http://www.ekonomiaspoleczna.gov.pl/

European Research Network. 2013. Available on the Internet: http://www.emes.net/index.php?id=203

Fernandes, M. 2009. Statistics for Business and Economics. Frederiksberg, Denmark: Marcelo Fernandes and Ventus Publishing ApS.

Galera G., Borzaga C. 2009. Social enterprise an international overview of its conceptual evolution and legal implementation. Social Enterprise Journal, 5(3): 210-228. https://doi.org/10.1108/17508610911004313

Haugh, H. 2012. The importance of theory in social enterprise research. Social Enterprise Journal, 8(1): 7-15.

https://doi.org/10.1108/17508611211226557

Kerlin, J. A. 2006. Social Enterprise in the United States and Europe: Understanding and Learning from the Differences. Voluntas, 17:247263. https://doi.org/10.1007/s11266-006-9016-2

Matwiejczuk, R. (2000). Effectiveness - an attempt at definition, Organization Review, 11: 27-31.

Miles, M.P., Verreynne, M.-L., Luke, B. 2014. Social Enterprises and the Performance Advantages of a Vincentian Marketing Orientation. Journal of Business Ethics 123(4): 549-556. https://doi.org/10.1007/s10551-013-2009-3

Pacut, A. 2010. Social entrepreneurship in Poland - problems and challenges, Zarządzanie Publiczne, 4(14): 45-58. Available on the Internet: http://cejsh.icm.edu.pl/cejsh/element/bwmeta1.element.desklight-7df4d96e-c8bc-48b7-a725-5eae572284b1

Pestoff, V., Hulgård, L. 2016. Participatory Governance in Social Enterprise. Voluntas: International Journal of Voluntary \& Nonprofit Organizations, 27(4): 1742-1759: https://doi.org/10.1007/s11266-015-9662-3

Potluka, O. 2017. How effective and efficient is the public support granted to social enterprises?, CEPS Working Paper Series, 11: 1-23. Available on the Internet: https://edoc.unibas.ch/61145/1/20180226112707_5a93e0fb207c0.pdf

Przygodzka, R. 2008. Effectiveness of the public sector, Optimum, 4(40): 153-169. Available on the Internet: http://cejsh.icm.edu.pl/cejsh/element/bwmeta1.element.e2e303e6-44e0-34b5-b5bc-7cc9f432eb55

Ramus, T. Vaccaro, A. 2017. Stakeholders Matter: How Social Enterprises Address Mission Drift. Journal of Business Ethics 143(2): 307322. https://doi.org/10.1007/s1055

Ridley-Duff, R. J. 2015. The Fair Shares Model: an ethical approach to social enterprise development?, Ekonomski vjesnik/EconviewsReview of Contemporary Business, Entrepreneurship and Economic Issues 28(1): 43-66. Available on the Internet:

https://hrcak.srce.hr/ojs/index.php/ekonomski-vjesnik/article/view/3157

Staicu, D. 2018. Financial sustainability of social enterprise in Central and Eastern Europe, Proceedings of the International Conference on Business Excellence, 12(1): 907-917. https://doi.org/10.2478/picbe-2018-0081

Thompson, J., Doherty, B. 2006. The diverse world of social enterprises. A collection of social enterprise stories. International Journal of Social Economics, 33(5/6): 361-375. https://doi.org/10.1108/03068290610660643

Wesołowski, W.J. 1996. Research methodology in the field of management sciences. Warsaw, Poland: Prywatna Wyższa Szkoła Handlowa w Warszawie. 


\section{ENTREPRENEURSHIP AND SUSTAINABILITY ISSUES}

ISSN 2345-0282 (online) http://jssidoi.org/jesi/

2020 Volume 7 Number 3 (March)

http://doi.org/10.9770/jesi.2020.7.3(43)

\section{Acknowledgements}

The publication was written as a result of the author's internship at Edinburgh Napier University, co-financed by the European Union under the European Social Fund (Operational Program Knowledge Education Development), carried out in the project Development Program at the University of Warmia and Mazury in Olsztyn (POWR.03.05. 00-00-Z310/17)
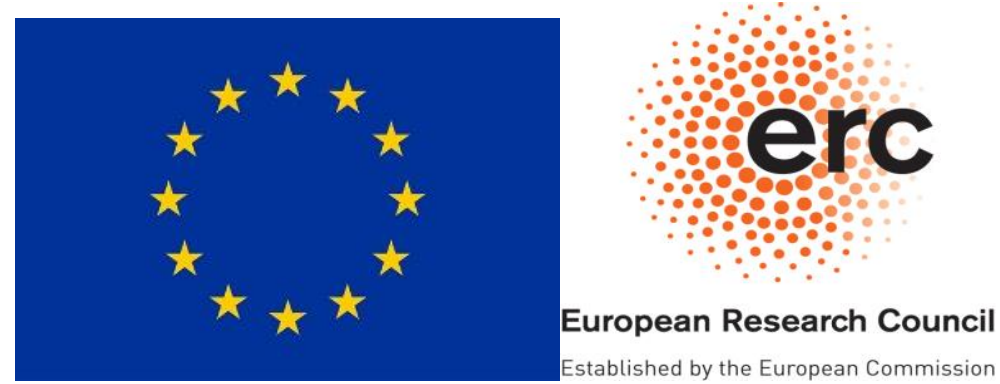

Marian OLIŃSKI is the Professor of Institute of Management and Quality, Faculty of Economics, University of Warmia and Mazury in Olsztyn. An expert and head of research teams implementing scientific projects financed by the Ministry of Science and Higher Education and the European Union. A member of Polish and foreign scientific associations. Business adviser in the field of social entrepreneurship Research interests: social entrepreneurship, activity of non-governmenta organizations, business model concept.

ORCID ID: orcid.org/0000-0002-1707-0553

Register for an ORCID ID:

https://orcid.org/register

Copyright (C) 2020 by author(s) and VsI Entrepreneurship and Sustainability Center

This work is licensed under the Creative Commons Attribution International License (CC BY).

http://creativecommons.org/licenses/by/4.0/

(c) (†) Open Access 